\title{
A vida e os tempos de João Gomes: escravidão, negociação e resistência no Atlântico negro*
}

The life and times of João Gomes: slavery, negotiation and resistance in the Black Atlantic

\section{Mary Ann Mahony"*}

Resumo: Até pouco tempo, os historiadores acreditavam que era impossível aprender muita coisa sobre a vida pregressa de pessoas escravizadas no Brasil que nasceram na África. Com base na nova historiografia da África e do Mundo Atlântico, assim como materiais como o banco de dados www.slavevoyages.org, historiadores do Brasil conseguem traçar as experiências de africanos escravizados antes e depois da sua chegada ao Brasil. A reconstrução deste Mundo Atlântico revela a maneira em que educação e experiência, numa conjuntura histórica específica, desenvolveram as noções de escravidão, comunidade e liberdades dos africanos escravizados no Brasil. Este trabalho reconstrói a história da vida de João Gomes, um homem escravizado, nascido na primeira metade do século XIX, de origem congo em Angola, mas que como adulto viveu escravizado em Ilhéus, Bahia. Fazer essa reconstrução revela por que ele escapou da fazenda onde sofreu o cativeiro, por que ele não gostou da vida de quilombola e por que confessou um crime que provavelmente não cometeu. A história de Gomes revela que entender o contexto histórico específico no qual nasceram, em vez de imaginar um passado geral "africano", é essencial para entender os pensamentos, emoções e estratégias para sobrevivência das pessoas escravizadas no Brasil.

Palavras-chave: Escravidão e resistência; quilombo; Mundo Atlântico

\footnotetext{
* Traduzido do original em inglês por João Lins Costa Sobrinho, com revisão da autora.

** Professora do Departamento de História da Central Connecticut State University (New Britain, Estados Unidos) e Ph.D. pela Yale University.
} 
Abstract: Until recently, historians believed that it was impossible to learn much about the early years of Africans enslaved in Brazil. On the basis of the new historiography of Africa and of the Atlantic World, as well as materials such as the data base www.slavevoyages.org, historians of Brazil are now increasingly able to trace the experiences of enslaved Africans before and after they arrived in Brazil. Reconstructing this Atlantic World reveals the ways in which education and experience in a particular African historical conjuncture shaped the notions of enslavement, community and freedom of African captives in Brazil. This paper reconstructs the life history of João Gomes, an enslaved man born in the first half of the nineteenth century to Kongo parents in Angola, but who spent much of his adulthood in slavery in Ilhéus, Bahia. Tracing his past in Africa and in Brazil allows us to see why he escaped from the plantation on which he was enslaved, why he despised life in the quilombo that he and his workmates established, and why he confessed to a crime that he did probably not commit. Gomes' story makes clear that understanding the specific historical context in which they were born, rather than assuming a generalized "African" past, is essential to understanding the thoughts, emotions and strategies for survivals of Africans enslaved in Brazil.

Keywords: Slavery and resistance; quilombo; Atlantic World

Em 2I de abril de I875, João Gomes apresentou-se na residência do juiz de direito de Ilhéus, Bahia, armado com um facão e um clavinote e confessou ter tentado assassinar Fortunato Pereira Gallo, o dono do Engenho Santo Antônio da Ribeira das Pedras. As autoridades ficaram chocadas: não podiam entender porque Gomes, que "andava errante pelos matos, fugido da casa de seu senhor" há mais de dois anos, teria se entregado voluntariamente, especialmente dado que Gallo identificou dois outros homens escravizados muito mais jovens que Gomes - como os autores do ataque. Suspeitaram ser algum tipo de truque. Acharam que o quilombola estava mentindo para proteger seus parceiros no quilombo e que ele só se entregava porque os proprietários locais e a forca pública da Bahia estavam buscando nas matas pelos homens acusados por Gallo. ${ }^{\text {I }}$

\footnotetext{
${ }^{\text {I }}$ Agradeço a Joseph Miller e os membros do seminário "Africa in the History and Culture of the Americas" e participantes da ASWAD - Association for the Study of the Worldwide African Diaspora (Associação para o
} 
$\mathrm{Na}$ interrogação que se seguiu, Gomes se esforçou para convencê-los de que fora ele o responsável pelo ataque e que atuara sozinho. Informou que fugiu do engenho onde "empregava-se na enfermaria, olaria e lavoura do seu senhor", por causa dos abusos e injustiças que sofria as mãos de Gallo. Durante seu tempo na liberdade ele vivia nas matas perto da Lagoa Pequena com seis outros. Lá, construíram uma casa pequena e se sustentaram plantando milho e feijão, assim como colhiam piaçava para vender aos escravos de Barra do Rio de Contas (hoje Itacaré), dos quais ele comprou a arma de fogo. Porém, "não podendo mais suportar a vida de animal bravio deliberou vir até junto do engenho para saber o que se passava", pensando "em pedir a seu senhor para ser vendido. " Chegando perto da fazenda, "teve medo que o mesmo seu senhor o surrasse" e, quando "ouviu a voz do seu senhor [...] pensou em matá-lo para ser morto também, e que então disparou a arma que trazia”. ${ }^{2} \mathrm{O}$ ataque, segundo Gomes, foi espontâneo, provocado por raiva e o desejo de se vingar do senhor. Rendeu-se às autoridades, porque "sendo-se já perdido confiou na justiça e veio entregar-se para que não ficasse outros culpados". Perguntado porque ele preferiu entregar-se que voltar a viver na liberdade, ele respondeu que "imaginando que há deus no céu e justiça na terra" decidiu não voltar para as matas.

Gomes repetiu sua confissão às autoridades três vezes e, também, admitiu sua culpabilidade às pessoas que pararam para falar com ele pelas grades da janela da cadeia de Ilhéus. No entanto, quando foi perguntado frente ao júri, ele renegou sua confissão dizendo que tinha mentido anteriormente. Continuou a insistir que não podia "suportar viver mais no mato", mas agora disse que confessou o crime para "livrar-se do poder de seu senhor". Embora Gomes tenha se retratado de sua confissão, nunca implicou outra pessoa no ataque. Insistiu que não foi ele quem atirou em Gallo, mas também negou saber quem tinha sido. Insistiu, absolutamente, que tampouco foram seus parceiros os atacantes. Sabia do crime por ouvir dizer e decidiu confessar porque estava "desesperado de sua vida" na mata. Em outras palavras, indicou que preferia a escravidão em outro lugar à liberdade nas matas de Ilhéus. ${ }^{4}$

Seus interrogadores não entendiam - e talvez não se importassem - com o que ele estava tentando dizer. Até pouco tempo, os historiadores tampouco o teriam entendido. O

Estudo da Diáspora Africana no Mundo) e da CLAH - Conference on Latin American History (Conferência de História Latino-americana), por comentários em versões anteriores deste artigo.

${ }^{2}$ ARQUIVO PÚBLICO DO ESTADO DA BAHIA (doravante, APEB). Seção: Judiciária (doravante SJ). Processocrime No 2I/748/9. Tribunal de Justiça, Tentativa de homicídio, Réu: João Gomes, escravo, I875, ff. I2-I5; I8; 38-40.

${ }^{3}$ APEB/SJ. Processo-crime No 2I/748/9, ff.67f-68v.

${ }^{4}$ APEB/SJ. Processo-crime No 2I/748/9, ff.67f-68v. 
silêncio no qual os escravocratas confinaram pessoas como Gomes foi estendido aos historiadores. As denominações reducionistas de "africanos" e "crioulos", com as quais as autoridades os rotulavam, passaram para a história como categorias com algum significado. De fato, dizem muito pouco e escondem as complexidades das experiências pessoais e dos legados culturais que formaram as interações das pessoas escravizadas no Brasil, entre si e com os seus opressores.

Até pouco tempo, os historiadores acreditavam que era impossível aprender muita coisa sobre a vida pregressa de pessoas escravizadas no Brasil que nasceram na África. Citando o antropólogo Eric Wolf no seu estudo clássico, eles eram povos considerados "sem história" (WOLF, I982, p. 4). Alguns historiadores e antropólogos tentaram identificar elementos da cultura africana que sobreviveram à travessia do Atlântico, numa busca por permanências ou, nas palavras de Herskovits, resíduos de "africanismos em seu comportamento cultural" (HERSKOVITS, I930, pp. I45-I55) . Estes pesquisadores consideraram as afiliações étnicas na África como construções ahistóricas, que não mudaram durante o tempo, e os povos Africanos como grupos sujeitos a forças históricas fora do seu controle em vez de agentes da história tentando controlar suas vidas em circunstâncias difíceis (MILLER, I999, pp. I6-I7). Pierre Verger foi um dos primeiros a contradizer esta abordagem da história afro-brasileira. Em uma série de estudos a partir dos anos 1960, ele defendeu uma compreensão mais dinâmica da interação entre o Brasil e a África, que levasse em conta os "fluxos e refluxos" desta interação (VERGER, 1968). Em outras palavras, ele defendia a tese de que cada um dos dois lugares tem histórias e que há uma influência mútua. Desse modo, ele antecipou em décadas a recente guinada em direção à conceitualização do Mundo Atlântico desenvolvido por historiadores no Brasil, na África, Europa e nos Estados Unidos. ${ }^{5}$

Esta nova direção na historiografia, sobre o Mundo Atlântico e novos intercâmbios entre historiadores que estudam Brasil, África e o comércio de escravos no Atlântico, abre caminhos para reconstruir a história que pessoas como João Gomes estavam tentando contar ou, ao menos, parte dela. Para reconstruir a experiência de homens e mulheres africanos que

\footnotetext{
${ }^{5}$ A visão do mundo atlântico e sua importância para a história da diáspora africana desenvolveu-se a partir de conversas e debates entre pesquisadores de quatro continentes. Entre os trabalhos neste ramo da historiografia, destacam-se, sobre o mundo atlântico português, REIS, GOMES E CARVALHO, 20I0; CANDIDO, 20I3; FERREIRA, 2012; 2006; HAWTHORNE, 2008; FLORENTINO, 2002; CURTO E LOVEJOY, 2004; SWEET, 2003; HEYWOOD, 2002; MILLER, 2002; ALENCASTRO, 2000; THORNTON, 1998; MILLER, 1988. Sobre o Atlântico falante de inglês, ver, dentre outros, LINEBAUGH E REDIKER, 2000; GILROY, I993; BERLIN, I998; GOMEZ, 1998. Sobre o circum-Caribe ver PUTNAM, 2006.
} 
foram escravizados no Brasil, é preciso investigar as circunstâncias específicas nas quais eles viveram desde o nascimento na África até sua morte no Brasil, passando por sua experiência como cativos nos navios negreiros. Assim, torna-se possível enxergá-los como atores históricos, limitados pelos seus escravizadores, em vez de enigmas cujas ações não se pode tentar compreender. Por esta ótica, pode-se ver os africanos escravizados no Brasil como pessoas usando todas as suas experiências e conhecimentos para tentar ter algum controle sobre suas vidas, dentro dos limites da escravidão (CURTO e LOVEJOY, 2004; REIS, 2003; FLORENTINO, 2002; MILLER, 2002; HEYWOOD, 2002; ALENCASTRO, 2000). O objeto deste artigo é revelar a complexidade da vida de João Gomes, ao colocar suas palavras no contexto da conjuntura histórica que em ele vivia. Ao fazê-lo, podemos explicar por que Gomes provavelmente confessou um crime que ele não cometeu e porque ele preferiu a escravidão fora de Ilhéus à liberdade na Mata Atlântica.

\section{João Gomes na documentação}

Numerosos documentos permitem reconstruir parte significativa da vida de João Gomes, antes e depois ser levado para o Brasil. Dentre estes, há uma série de ofícios enviados pelo juiz de direito de Ilhéus para o presidente da província da Bahia e o processo-crime que documentou o fato, a investigação, o julgamento, a condenação, a sentença e a apelação.

A transcrição do julgamento deixa claro que Gomes foi interrogado quatro vezes, sendo três vezes como parte da investigação e uma vez em audiência, diante do júri. Cada interrogatório começava com uma qualificação do réu, de acordo com as regras previstas no Código do Processo Criminal de Primeira Instância de I832. O promotor perguntou o nome, filiação, idade, nacionalidade, naturalidade, estado civil, ocupação e grau de instrução de Gomes quatro vezes, durante os dois meses passados entre a investigação do crime e o julgamento. Depois de Gomes ter respondido as qualificações, o promotor continuou por perguntar sobre o ataque e a vida como fugitivo, duas vezes antes, durante a investigação e uma vez frente ao júri.

As respostas que Gomes deu permitiram elucidar alguma coisa sobre o seu pensamento. Ele revelou que se chamava João Gomes, era filho de Gomes Maland, que não tinha certeza de quantos anos tinha, mas achava que contava cerca de 6o, era de nacionalidade do Congo, nascido no "Reino de Angola", na cidade de Luanda, solteiro, analfabeto e que 
trabalhava na agricultura, fabricação de tijolos e enfermaria na fazenda de seu proprietário. ${ }^{6}$ Abrem, também, uma janela para os pensamentos de João Gomes, este homem que parecia preferir escravidão a liberdade nas matas de Ilhéus.

É razoável questionar até que ponto as informações nos documentos refletem as palavras e a maneira de pensar de Gomes. Historiadores, há muito tempo, já sabem que as elites moldam os depoimentos de homens e mulheres que, como ele, se veem em um sistema legal que lhes é hostil. As diferenças entre os interrogadores e o interrogado no que diz respeito a status, etnia, educação e experiência eram enormes; ainda que o medo e a desconfiança mútua não influenciassem as suas interações, eles teriam dificuldades para entender um ao outro. Porém, historiadores também demonstraram que é possível enxergar algo das atitudes e aspirações dos oprimidos em registros judiciais, em que pese a forte presença das elites nos documentos. O testemunho de Gomes não é exceção. Ele foi filtrado pelas perguntas que a polícia, o promotor e o juiz fizeram, pela informação que o escrivão registrou e pelas respostas que João Gomes pensou que ajudariam no seu caso. Apesar destas limitações, algo da pessoa de João Gomes vem à tona nos autos. Seus depoimentos para as autoridades foram mediados pelas diferenças de poder e autoridade entre ele e seus interrogadores, mas, ainda assim, contêm informações que ele lutou para incluir ali. Suas respostas, embora filtradas pelas informações que os servidores escolheram registrar, deixam claro que ele entendia as perguntas feitas e que ele respondeu de uma forma que ele acreditava que faria sentido para eles.

Isso se torna particularmente claro nas respostas de Gomes às perguntas sobre sua nacionalidade e lugar de nascimento. Sempre que lhe perguntavam sobre sua nacionalidade, ele dizia ser do Congo, mas, quando ele era perguntado onde tinha nascido, ele dizia que no "Reino de Angola" ou na "cidade de Luanda". Ele fazia claramente a distinção entre a origem étnica e o lugar de nascimento, do mesmo modo que as perguntas da qualificação buscavam especificar, assim como outro homem poderia se identificar como um português nascido no Rio de Janeiro. ${ }^{7}$

\footnotetext{
${ }^{6}$ APEB/SJ. Processo-crime No 2I/748/9, ff. I2-I5; f. I8; f. 38-40; 66-70. Nem sempre é possível encontrar informações tão detalhadas sobre um prisioneiro escravizado. Mattos (I992), por exemplo, comenta que as autoridades não perguntaram daquela forma sobre as informações de origem do réu em nenhum dos casos de escravos africanos que ela pesquisou. As autoridades sim perguntaram sobre as origens dos malês envolvidos na revolta de I835 em Salvador, mas aqueles africanos também eram incomuns, tendo organizado um sério desafio ao controle da elite na Bahia, falando e escrevendo em árabe, assim como em português, conforme REIS (2003). Fraga (2006) encontrou testamentos de Africanos na Bahia com informações muito detalhadas.

${ }^{7}$ APEB/SJ, Processo-crime, No. 2I/748/9, ff. I2-I5; f. I8; f. 38-40; 66-70.
} 
As autoridades muito dificilmente o teriam descrito da mesma forma. Embora elas, às vezes, usassem termos específicos para descrever os lugares de origem dos escravos, os donos de escravos brasileiros e seus representantes, a princípio, referiam-se aos homens e mulheres nascidos na África, simplesmente, como africanos. Em Ilhéus, não era diferente. De fato, foi assim com as autoridades ao longo do processo. $\mathrm{Na}$ verdade, era bastante incomum que proprietários de escravos, oficiais do governo ou representantes da igreja usassem qualquer outro termo em qualquer documento produzido por eles. Se o faziam, nunca usavam múltiplos termos - africano, Congo, Reino de Angola e Luanda - juntos. Os termos Congo, Reino de Angola e Luanda aparecem nos autos apenas nos depoimentos de Gomes para o promotor, em nenhum outro lugar. Desse modo, é mais provável que o seu aparecimento seja reflexo de suas falas do que das autoridades que o estavam interrogando.

Isso não significa que o colonialismo e a escravidão não tenham influenciado o que Gomes falou. Os termos para nacionalidade e lugar de nascimento que ele reportou às autoridades - África, Congo, Reino de Angola e Luanda - refletiam conceitos europeus vagos acerca de lugar e etnicidade na África e subestimavam grosseiramente as complexidades das identidades das pessoas por eles descritas. Os portugueses denominavam de Congo as pessoas que vinham da área ao redor do rio Zaire. Desde o começo do século XVII, eles usavam o nome "Reino de Angola" para se referir a Luanda e as regiões africanas próximas à cidade, situadas no interior e que estavam sob controle português. Por volta do século XIX, eles utilizavam, indistintamente, os termos Luanda e Angola para identificar os indivíduos que foram vendidos para a escravidão europeia a partir do porto de Luanda ou Benguela. Em nenhum dos casos esses termos indicam uma origem étnica ou geográfica específica, já que, à época, não existiam entidades políticas conhecidas como Reino de Angola ou Congo e pessoas com variadas identidades e de uma ampla variedade de lugares foram inseridas no comércio transatlântico de escravos de cima a baixo da costa ocidental centro-africana (MILLER, 2002, p. 29).

Estas, seguramente, não eram as denominações que os africanos da parte central da costa ocidental utilizavam para descrever uns aos outros. No momento em que Gomes chegou no Brasil, estes habitantes viviam em pequenas vilas rurais independentes e ter-se-iam identificado como sendo residentes destas vilas, assim como pertencentes a um lar ou uma linhagem (MILLER, 2002 pp. 9, 29; MILLER, 1988, p. 23). Embora todos os africanos da parte central da costa ocidental tivessem muitas características em comum, incluindo agricultura, o 
cotidiano na vila e línguas derivadas do Banto, Joe Miller argumenta que eles, no entanto, enxergavam a si mesmos em termos mais locais do que regionais ou continentais antes do contato com o comércio de escravos português (VANSINA, I990; MacGAFFEY, 2000, pp. 8-9). O uso de termos tão amplos por Gomes, desse modo, refletia o contato com a escravidão e com os europeus e seus representantes. Em outras palavras, eles refletiam a sensibilidade de um homem que tinha um entendimento claro de como ele deveria se comunicar com os homens que falavam português.

O uso destes termos vagos europeus por Gomes refletem mais do que a sua adoção do discurso colonial hegemônico. A combinação dos termos que ele utilizou sugere, antes, que ele se esforçava para explicar algo bem específico para as autoridades - de um modo que ele pensou que entenderiam. Isso se torna particularmente claro quando, seguindo a direção de novos estudos sobre história do Atlântico, se olha para além da costa da Bahia e se considera a história dos lugares que os europeus chamavam de Congo e Angola, situando Gomes em um contexto histórico específico.

Para fazê-lo, deve-se precisar a idade de Gomes e o momento em que foi trazido para o Brasil. Isso é um tanto difícil, porque ele era um homem com um senso cronológico bastante vago, característica das pessoas rurais como um todo, escravizadas ou livres, na época. Ele disse aos investigadores que ele tinha cerca de 60 anos - porém, não tinha certeza - e que ele não sabia por quanto tempo tinha sido escravizado no Brasil. O promotor reconheceu que, ao olhar para Gomes, poder-se-ia dizer que tinha cerca de 6o, mas seguramente não mais que isso. Um ano antes, no entanto, seu proprietário tinha dito às autoridades que ele tinha quarenta e um anos. ${ }^{8}$ Isso não quer dizer, necessariamente, que as estimativas do senhor eram mais corretas que as do cativo. Todos concordaram que Gomes ainda trabalhava na fazenda quando ele escapou, bem como que ele passou dois anos vivendo na floresta, com sucesso. Dada a realidade da nutrição e condições de vida na escravidão, bem como o terreno acidentado e a floresta densa da área em que ele viveu depois da fuga, ele dificilmente teria conseguido se sair tão bem se tivesse realmente sessenta anos de idade. Por outro lado, é plenamente possível que ele estivesse na casa dos quarenta anos e aparentasse ter sessenta. Alternativamente, tanto ele como Gallo poderiam ter indicado idades simbólicas: Gallo, tentando mostrar que seu escravo tinha meia idade, mas ainda era capaz de trabalho duro e

\footnotetext{
8 APEB, Seção Histórica (doravante, SH), Classificação dos escravos para serem liberados pelo Fundo de emancipação. Ilhéus, I874-I884 (doravante Classificação dos escravos).
} 
Gomes, indicando o seu papel como pessoa mais velha na comunidade. O significado disto será discutido a seguir, mas agora é suficiente indicar que, em I875, João Gomes tinha entre quarenta e sessenta anos de idade, logo, provavelmente, nasceu entre I8I5 e I835.

\section{João Gomes em Luanda}

$\mathrm{Na}$ primeira metade do século XIX, o trecho da África Ocidental Central que os portugueses chamavam Angola era uma das regiões de influência portuguesa no continente. Os centros coloniais estavam em duas cidades - Luanda e Benguela - e seus arredores, no interior. Naquela época, apenas cerca de 5.000 pessoas viviam na cidade de Luanda, mas cerca de 500.000 pessoas viviam na região mais ampla, abrangendo Benguela e uma grande variedade de aldeias rurais sob alguma forma de controle português, direto ou indireto e vários graus de interação com os europeus (HEYWOOD, 2002, p. 95; MILLER, 2002, p. 29).

A economia colonial era baseada na escravidão. Muitos dos africanos que viviam neste domínio colonial foram escravizados pelos portugueses e luso-africanos de Angola, para trabalhar em suas casas, nas ruas, nos portos e nas lavouras (FERREIRA, 20I2, pp. I28-I38; CURTO e GERVAIS, 200I, p. 4I; CURTO, I999). No século XIX, o tamanho dessa população escravizada oscilou de acordo com a demanda brasileira de escravos e a oferta de novos escravos do interior, mas permaneceu uma população escravizada mais ou menos permanente, suplementada por indivíduos em trânsito que estavam sendo mantidos perto da costa, enquanto aguardam a exportação para o Brasil (FERREIRA, 20I2, p. I28; CURTO e GERVAIS, 200I, p. 4I). Os navios negreiros aportavam em Luanda e Benguela para obter cativos a serem vendidos nas Américas. De acordo com uma estimativa, "das imediações de Luanda foram despachados, entre I837 e I840, perto de 77.00o cativos" (REIS, GOMES e CARVALHO, 20Io, p. II6).

A cidade de Luanda é mencionada no relato de um viajante estrangeiro, o europeu George Tams. Ele ficou impressionado com as casas cobertas com telhas, "edifícios como o da alfândega e o da praça de comércio, por sua boa construção e imponência" (REIS, GOMES e CARVALHO, 20I0, p. II7). A pequena comunidade branca mantinha os costumes europeus ou ao menos tentava. Porém, na sua maioria, os brancos da cidade eram agentes de firmas negreiras estabelecidas em Portugal ou no Brasil (REIS, GOMES e CARVALHO, 20IO, p. II9). A sociedade e cultura nesta região eram luso-africanas, como resultado de dois séculos de 
contato entre vários grupos de africanos e portugueses (HEYWOOD, 2002, pp. 92-93). A pequena população branca - seja nascida em Portugal ou na África - vivia em Luanda e na cidade de Benguela, mais ao sul, junto com um grupo miscigenado muito maior e um grande número de africanos de várias partes do interior. Na grande zona rural, havia menos miscigenação, mas, assim como Luanda, era uma área onde africanos de várias origens viviam junto com colonos portugueses nascidos em Portugal, colonos portugueses nascidos na África e os africanos nascidos dentro da esfera de influência portuguesa (HEYWOOD, 2002, pp. 9395).

A cultura portuguesa não dominava completamente esta África controlada por Portugal. Vários funcionários portugueses se queixavam, regularmente, no século XVIII, que os africanos da região tinham africanizado os portugueses e seus descendentes que ali viviam mais do que os portugueses os tinham europeizado. $\mathrm{O}$ cristianismo era a religião oficial da África portuguesa e um grande número de africanos que foram integrados no sistema colonial não foram batizados como cristãos, mas as autoridades religiosas consideraram, na época, que suas crenças não eram compatíveis com o catolicismo. Da mesma forma, muitos africanos na região falavam português, mas as pessoas que tinham sido trazidas para essas cidades para aguardar o transporte para o Brasil trouxeram seus próprios idiomas com eles. Quimbundo e umbundo tornaram-se línguas francas africanas dentro da área, de acordo com Linda Heywood (2002). Todos esses africanos, cristãos e não cristãos, falantes de quicongo e português, não se davam bem: os cristãos no Congo oriental, no final do século XVII, viam seus "vizinhos, falantes de quicongo não cristãos, como mbumba, um termo depreciativo descrevendo uma pessoa rural sem sofisticação" (THORNTON, 2002, p. 89). Grande parte do poder político e religioso associado a um sentido cristão congo de superioridade tinha desaparecido pela primeira metade do século XIX, mas ideias semelhantes podem ter perdurado, inclusive entre os cristãos ao redor Luanda, dadas as circunstâncias ali encontradas.

Reconhecer a complexidade desta sociedade na África controlada pelos portugueses, na primeira metade do século XIX, nos ajuda a interpretar as declarações de Gomes às autoridades de Ilhéus. Ele dizia ter nascido na região sob domínio português ou nos arredores da cidade de Luanda, em uma família com origens nas aldeias ao longo do rio Zaire. Em outras palavras, disse-lhes que ele teve a experiência de vida urbana, de falar português e até mesmo de ser um cristão antes da sua chegada ao Brasil, mas ele se via como sendo etnicamente congo ou da "nação" do Congo. Ele estava também, provavelmente, tentando dizer que ele falava 
quicongo - ou uma das outras línguas do congo - e, possivelmente, quimbundo ou umbundo também. Ele também estava tentando dizer que ele era um homem sofisticado, acostumado a lugares que eram mais cosmopolitas do que Ilhéus, com suas plantações e fazendas espalhadas ao longo de um amplo território, cercada pela floresta tropical e com pouco contato com o mundo externo. ${ }^{9}$ Os sobrenomes que João Gomes relatou às autoridades de Ilhéus reforçam este argumento sobre o seu passado. Era uma prática comum no Congo dar aos meninos um nome próprio, seguido do primeiro nome de seu pai. ${ }^{\text {Io }}$ Assim, João Gomes era filho de Gomes Maland, que, por sua vez, era filho de Maland, cujo segundo nome não se conhece. Embora essa maneira de escolher os nomes fosse comum entre as pessoas que os portugueses identificavam como congo, estes não eram nomes puramente congos - dois dos três eram cristãos e portugueses, em vez de africanos. Este uso de nomes portugueses e cristãos em combinação com nomes africanos teria sido comum, de acordo com Linda Heywood, entre os africanos que viviam dentro ou perto de áreas luso-africanas. Segundo ela, por volta do século XVIII, em Benguela e, presumivelmente, também em Luanda, os africanos que viviam na esfera da sociedade luso-africana, mas não tinha sido batizados, adicionavam nomes portugueses, mas não cristãos, a seus nomes africanos, enquanto aqueles que tinham sido batizados, a maioria dos quais eram escravos, usavam nomes cristãos. Desta forma, Gomes Maland poderia ter sido um africano não-cristão escravizado que vivia na esfera da cultura luso-africana, enquanto João Gomes poderia muito bem ter sido o seu filho cristão escravizado (HEYWOOD, 2002, pp. IO2-IO3).

A escolha de Gomes como prenome do pai de João Gomes é sugestiva e interessante. Pesquisas recentes feitas por Roquinaldo Ferreira revelam que um dos traficantes de escravos mais importantes no mundo atlântico na primeira metade do século XIX chamava-se Francisco Ferreira Gomes. O comerciante, “um homem negro nascido no Brasil,"“envio quase 7 mil cativos de Benguela para o Brasil” entre I809 e I83I antes de voltar ao Rio de Janeiro em I834. Continuou traficando em seres humanos depois de mudar ao Rio, mas os negócios em Benguela foram administrados por José Ferreira Gomes, seu filho mais velho (FERREIRA, 20I3, p. 68I; 20I2, p. 203). Embora João Gomes tenha nascido em Luanda e não em Benguela,

\footnotetext{
${ }^{9} \mathrm{Na}$ época, Luanda era menor que Salvador ou Rio de Janeiro, mas muito maior que o vilarejo de São Jorge dos Ilhéus. Viviam umas 5.600 pessoas no município de Ilhéus em I872, mas apenas cerca de I.ooo viviam na sede. A maioria vivia numa extensiva zona rural de pequenos engenhos, serrarias, fazendas, roças e povoados cercada de mata atlântica.

${ }^{\text {Io }}$ MacGAFFEY, Comunicação pessoal. I8 de setembro de 2003; ver, também, as informações sobre práticas de escolher nomes e apelidos entre os congo em MacGAFFEY, I970. p. 96-99.
} 
pode ser que o nome do pai e dele reflitam alguma conexão com estes traficantes importantes e possam ajudar a entender como João Gomes terminou sendo vendido para o Brasil.

O nome do avô Gomes oferece mais pistas para as suas origens. As autoridades brasileiras eram rotineiramente descuidadas ao gravar os nomes das pessoas com nomes estrangeiros, especialmente quando eles eram analfabetos. De acordo com MacGaffey, o nome Maland, neste caso particular, pode ser uma grafia descuidada de um nome quicongo, Malanda. Esse poderia ser o caso, especialmente se Gomes estivesse pronunciando o nome em uma língua banta que incentivasse a supressão das sílabas finais. Em quicongo, malanda deriva de landa (seguir) e, geralmente, significa "aquele que segue". Na década de I960, quando MacGaffey estava conduzindo sua pesquisa original, Malanda normalmente significava "aquele que responde" em um processo judicial, ou o último na sequência de graduados das escolas nkimba para a educação de meninos que se desenvolveram no século XIX, com o declínio da chefia (Comunicação pessoal, I8 set, 2003). Somente indivíduos livres da comunidade eram autorizados a seguir a formação nkimba (MacGAFFEY, 1970, p. 249; 2000, p. I53). No entanto, o avô de João Gomes teria nascido em algum momento na segunda metade do século XVIII, quando a chefia era mais forte e quando, potencialmente, landa poderia ter outros significados. Um desses significados poderia ter sido escravo, uma vez que "aquele que responde" e "aquele que segue" poderia facilmente descrever o papel de uma pessoa escravizada. É possível que o avô de Gomes tenha sido um escravo dentro de uma comunidade africana antes de entrar em contato com o poder português. Seguindo esta lógica, João Gomes pode ter pertencido à segunda ou terceira geração de sua família a experimentar a escravidão, embora ele teria sido a primeira geração a vivenciar a escravidão no Brasil. Não causa admiração que ele acreditasse que a sua venda pudesse resolver alguns dos seus problemas ele estava ciente de que os escravos podiam ter uma grande variedade de experiências.

João Gomes adquiriu mais do que familiaridade com a escravidão europeia e muitos grupos de africanos enquanto esteve em Angola. Ele também aprendeu sobre certo e errado, comunidade, liderança e poder. Em outras palavras, ele desenvolveu uma visão de mundo que o ajudou a distinguir o bem do mal, e o possível do impossível. A capacidade de sobreviver dentro da escravização europeia foi outra aquisição, aprendida antes de chegar ao Brasil e não depois.

Gomes provavelmente foi criado por pessoas cujas ideias sobre o parentesco iam muito além da família nuclear. O clã e a linhagem foram as principais formas de organização social 
entre as pessoas a quem os portugueses chamavam de "Congo", mas os "congos" reconheciam suas relações com parentes ao longo das linhas materna e paterna. Essas noções sobre o parentesco eram complexas, relacionais e fluidas: termos para mãe, pai, irmão, irmã, primo e avô não se referiam a uma família nuclear específica e suas conexões imediatas, mas em vez disso tendiam a refletir relações dentro do clã (MacGAFFEY, I970, pp. 84-90). Irmão e primo, portanto, poderiam ser usados para descrever relacionamentos com as mesmas pessoas, ou para as pessoas com quem não se tinha ligações sanguíneas próximas. Estas formas de enxergar o parentesco, de acordo com MacGaffey, poderiam permitir aos povos congo racionalizar a cooperação entre as pessoas que poderiam ser identificadas como "família", mas com quem não se tinha laços de sangue (MacGAFFEY, I970, p. 90). Tais concepções podem significar que as pessoas de diferentes aldeias, ou mesmo de diferentes regiões da costa africana ocidental central, poderiam vir a se ver como membros da mesma "família", se passassem tempo suficiente juntos. Tais noções de parentesco poderiam se desenvolver de forma particularmente forte entre grupos de pessoas escravizadas com raízes que estavam ao longo do rio Zaire, mas que foram forçados a viver em Luanda e que continuamente conheceram recém-chegados do interior e, depois, os viu serem carregados em navios negreiros com destino ao Brasil.

Provavelmente, Gomes tinha sido criado por pessoas cujas ideias sobre liderança também eram bastante fluidas. O território em que as aldeias "congo" estavam situadas na primeira metade do século XIX já havia sido, outrora, reivindicado como o domínio do Reino de Kongo, o reino africano dos séculos XVI e XVII, cujo nome provém de um governante que tinha aceitado emissários portugueses e que se converteu ao cristianismo no século XV (THORNTON, 2002, pp. 72-3). Por volta do século XIX, este reino já não existia, embora caudilhos com poder político e militar comparativamente menor continuassem a competir pela legitimidade política associada à do rei Kongo. Esta competição, combinada com o comércio de escravos, tinha erodido seriamente a organização social e política nas aldeias do território ao longo do rio Zaire. A sociedade foi dividida em um pequeno número de homens livres ou chefes, os descendentes livres de escravos e escravas, mas, em um sinal da diversidade de origens e da mobilidade de muitos dos moradores destas aldeias, sociedades secretas e os direitos de iniciação para meninos adolescentes estavam se tornando comuns (MacGaffey, 2000, p. I53; I970, p. 242; MILLER, I988, p. 23-39). 
Nesse período, a liderança política era exercida por uma série de líderes, aos quais se pode melhor referir em inglês como chiefs (chefes), mas cujos títulos em quicongo - segundo Wyatt MacGaffey - refletia conceitos de propriedade e de responsabilidade para com as pessoas, em vez de liderança simplesmente política. Em sua opinião, a "característica comum" da chefia era que o chefe tinha poder para, dentre outras coisas, "ver claramente as coisas que são e as coisas que estão por vir". A chave para a posição do chefe era "a capacidade para fazer as coisas Para ele, esses chefes não eram tanto os ocupantes de ofícios reconhecidos ou posições herdadas, mas papéis "abertos em determinadas circunstâncias a uma figura adequadamente carismática" (MacGAFFEY, I970, p. 235). Em outras palavras, na época em que Gomes cresceu, a liderança dentro das comunidades congo estava aberta a qualquer homem adulto considerado por outros membros do grupo como sendo capaz de gerir ou "conhecer" uma determinada situação. Provavelmente, isso era especialmente verdadeiro nas comunidades escravizados no África portuguesa.

Com base nesta combinação de contexto histórico e de informações que ele forneceu às autoridades, podemos supor que João Gomes nasceu em Luanda entre I8I5 e I835, filho de pais escravizados, originários de uma aldeia situada ao longo do rio Zaire. Ele foi batizado no cristianismo no seu nascimento ou pouco depois, quando lhe foi dado um nome de batismo cristão e o primeiro nome de seu pai como um patronímico. Ele cresceu falando quicongo com sua família, mas também aprendeu português e uma ou ambas as línguas francas da região, a fim de comunicar-se com a grande variedade de pessoas com quem ele entrou em contato. Ainda criança, ele aprendeu lições de como sobreviver à escravidão europeia, que provavelmente incluía aprender algo sobre as noções portuguesas de moralidade e justiça. Ele também ouviu histórias sobre o Brasil. Ele trouxe essas noções e habilidades com ele quando seu dono luso-africano o vendeu a um comerciante de escravos, que colocou à força em um navio rumo ao Brasil.

\section{João Gomes e a travessia atlântica}

João Gomes foi levado para o Brasil em algum momento entre I830 e I85I. Em outras palavras, ele veio para o Brasil no final do tráfico de escravos, quando este era ilegal e quando navios britânicos e norte-americanos estavam patrulhando o Atlântico sul, parando e abordando navios negreiros. $\mathrm{Na}$ verdade, provavelmente houve uma conexão direta entre os 
esforços internacionais para deter o tráfico de escravos e a venda Gomes para ser escravizado no Brasil.

Na década de I830, Luanda já tinha sido, por mais de 200 anos, um ponto onde os escravos africanos do interior esperavam pelos navios para levá-los para o Brasil. Porém, a interferência britânica no comércio de escravos foi reduzindo a capacidade dos traficantes de escravos de aportarem em Luanda, assim como Benguela, o outro grande centro de escravização na parte central da costa ocidental africana. Consequentemente, traficantes traziam menos pessoas escravizadas do interior. Quando um comerciante de escravos chegava, frequentemente, não havia mais um número suficiente de cativos na cidade para atender à demanda e nem tempo de esperar para que outros fossem trazidos para o porto. Os mercadores de escravos de Luanda, então, começaram a vender um número crescente de pessoas escravizadas residentes, cristãos falantes de português, homens e mulheres, meninos e meninas da África Central lusófona para o Brasil. A demanda - logo, os preços - estavam altos, então os traficantes de Luanda tinham bons motivos para vender pessoas que não seriam, a princípio, vendidas no Brasil (CURTO, 2005, pp. IOO-I, II5; MILLER, I988, pp. 528-9). Sem dúvida, foi assim que João Gomes terminou em um navio rumo ao Brasil.

Embora os documentos não indiquem o navio no qual ele veio no Brasil nem onde ele desembarcou, sabemos um pouco sobre sua experiência. Primeiramente, sua travessia atlântica foi tão difícil como as outras. O navio estava lotado e as viagens eram longas, mesmo nas melhores circunstâncias. As 48 viagens registradas no banco de dados disponível em "slavevoyages.org" carregaram uma média de 385 pessoas cada, a travessia tendo a duração média de um mês. II Durante esse tempo, os cativos eram separados por sexo e apertadamente colocados no porão, com pouca comida, pouca água e pouco ar. Bem antes do fim da viagem, a disenteria e os enjoos deixavam o porão imundo e fétido (REIS, GOMES e CARVALHO, 2002, p. 80; MILLER, I988, pp.4II-2). Quando Gomes cruzou o oceano, ele tinha provavelmente entre Io e 20 anos de idade. De todo modo, seus companheiros de cativeiro eram, em sua maioria esmagadora, homens, e muitos eram crianças pré-adolescentes. Lovejoy estima que esses navios negreiros carregavam, em média, I88 homens para cada Ioo mulheres e que entre 40\% e $52 \%$ dos cativos tinham menos de $\mathrm{I} 3$ anos. Com o aumento da pressão sobre o tráfico de

\footnotetext{
${ }^{\text {II }}$ www.slavevoyages.org., Disponível em: http://www.slavevoyages.org/voyages/irj9gE2X. Acessado em I6 mar. 2016.
} 
escravos em Angola, os escravistas mandavam africanos cada vez mais jovens para o Brasil, um grande número deles sendo meninos (LOVEJOY, 2006, pp. 199-203).

A documentação sobre escravidão em Ilhéus, onde Gomes viveu sua escravidão brasileira, reforça as informações de Lovejoy. Em I86I, um escravo africano na fazenda de Homem d'El Rei, em Ilhéus, foi descrito como tendo apenas I8 anos. Se ele tivesse chegado no último navio que se acredita ter desembarcado escravos em Ilhéus - o Vencitore, em I85I - ele teria 8 anos quando sofreu a aterrorizante travessia atlântica. Em I872, ainda havia escravos africanos que, segundo seus donos, tinham apenas 38 ou 39 anos. ${ }^{12}$ Se estivessem no Vencitore, teriam no máximo I8 ou I9 anos quando fizeram a viagem.

Há três possibilidades sobre como Gomes chegou em Ilhéus. A Baía de Todos os Santos tinha sido o ponto de descarga mais importante para o nordeste antes de I830. Se Gomes tivesse desembarcado lá, teria sido vendido na cidade baixa e depois colocado em outro navio com destino a Ilhéus, na costa meridional da Bahia. Esta é uma possibilidade, porque o proprietário de Gomes, Fortunato Pereira Gallo, era o filho de um proeminente senhor de engenho no Recôncavo, que comprou vários cativos na praça de Salvador quando recebeu sua herança e se mudou para Ilhéus, onde reconstituiu uma parte significante de uma antiga sesmaria para criar uma propriedade agrícola chamada de Santo Antônio da Ribeira das Pedras, que produzia madeiras, açúcar, café e cacau. Alguns dos escravos que trabalhavam nas plantações nas décadas de I860 e I870 tinham nascido no Recôncavo e eram parte da sua herança, enquanto outros ele adquirira em outro lugar.

É possível que Gallo tenha comprado Gomes em Ilhéus, ou ao menos no sul da Bahia. Assim como na costa africana, os comerciantes de escravos tinham crescente dificuldade para trazer suas cargas aos portos tradicionais, neste caso, Salvador (TAVARES, 1988, pp. I7-23). Tais problemas, por sua vez, tornaram as vilas ao longo da costa remota da Bahia mais atraentes para os comerciantes chegando da África com suas cargas de escravos contrabandeados. Taipus de Fora, em Maraú, e Ilhéus, por esta razão, cresceram em importância para o contrabando de escravos entre I830 e I85I, embora não fossem os centros econômicos mais importantes na Bahia. A costa era, no entanto, um ponto excelente para a realização do

\footnotetext{
${ }^{12}$ BRASIL. DIRETORIA GERAL DE ESTATÍSTICA. Recenseamento da população do Brazil a que se procedeu no dia I de agosto de I872. Paróchia de São Jorge dos Ilhéos, População considerada em relação a nacionalidade brasileira; População considerada em relação á nacionalidade estrangeira. 2I vols de 22. Rio de Janeiro, I873-76. Microfilme. Vol. 3: 278. (doravante, Recenseamento de I872). APEB/SJ, Inventário No 02/786/1253/06, Maria José Scola del Rei e Josefina Carolina Scola del Rei, I86I.
} 
comércio de escravos de contrabando (MAHONY, 200I, pp. I03-5; CRUZ, 20IO, pp. I22-I27). Os vários quilômetros de costa do sul da Bahia incluem pequenos portos, que se abrem para três rios que, na maré alta, são navegáveis para grandes navios a vela. As colinas e escarpas alinhadas à costa dão aos observadores no mar a impressão de que estão olhando para um grupo de ilhas, mas também escondem os mastros e o cordame de navios no porto ou rio acima. Recifes ao longo da costa complicam o acesso ao porto, o que representava tanto uma desvantagem quanto uma vantagem: uma vez que um navio passasse por eles, não poderia ser facilmente seguido por navios de guerra grandes e pesados.

Melhor ainda, a área era, para dizer o mínimo, apenas marginalmente sob o controle das autoridades governamentais no Rio e em Salvador. As margens do rio e o interior permaneciam fortemente arborizadas e a área era apenas levemente povoada. O número de plantações e fazendas estava crescendo, especialmente como resultado do comércio de madeira e da produção de açúcar, cacau e mandioca, mas o governo imperial mantinha quase nenhuma presença independente lá: em determinado momento, havia normalmente apenas um representante do governo na cidade que não era um membro da elite local ou um de seus clientes. Nas palavras do juiz encarregado de fazer cumprir as leis imperiais brasileiras neste lugar remoto, ele não era capaz de vigiar, dia e noite, mais de oitenta quilômetros de costa, um porto e vários rios navegáveis, especialmente por não ter nenhuma ajuda da elite local. ${ }^{13}$

Na década de I830, segundo o historiador baiano José da Silva Campos, um morador de Ilhéus reclamava que navios negreiros estavam aportando no porto, levando adiante o "comércio escandaloso e ilícito de africanos". Quando os funcionários do império começaram a fiscalizar o contrabando de escravos no Recôncavo em I848, registraram que os traficantes deslocaram suas operações para Ilhéus e Camamú (CAMPOS, I98I, pp. 228, 235). Em fevereiro de I85I, o juiz de direito informou a seus superiores que vários escravos foram desembarcados em um ponto do Rio do Engenho em Ilhéus para serem entregues em fazendas ao norte e ao sul da costa baiana (CRUZ, 20I0, pp. I22-I27; MAHONY, 200I, pp. IO2-I05). Em setembro do mesmo ano, mais algumas centenas de escravos foram desembarcados com sucesso em Ilhéus. Em outubro de 1855 houve um relato, não confirmado, de outro desembarque de africanos contrabandeados e, em abril de I856, os contrabandistas tentaram desembarcar mais escravos ao sul da vila de Ilhéus. Em I858, um dos fazendeiros que vivia próximo à Lagoa integrava a

\footnotetext{
${ }^{13}$ APEB/SH. Joaquim Rodriquez de Sousa, Juiz de Direito à Presidente da Província. I7 de fevereiro de I85I. Juízes, maço 2397 .
} 
lista de traficantes de carne humana. Os funcionários provinciais estavam desconfiados e mantinham um olhar atento sobre a cidade e, em algum momento, o contrabando de escravos cessou, mas não definitivamente, até pelo menos I858 (AVÉ-LALLEMANT 196I, p. 73; Bethell, I970, p. 359). ${ }^{\mathrm{I}}$

Qualquer que tenha sido a sua idade quando chegou ao Brasil, Gomes estava em péssima forma no momento em que ele desembarcou do navio. Todos os relatos sobre sobreviventes à travessia atlântica indicam que eles estavam fracos e raquíticos quando chegavam ao Brasil, uma vez que os comerciantes de escravos os alimentavam o suficiente apenas para mantê-los vivos, mas não o suficiente para encorajar a revolta. Depois de um mês no mar com água salgada e maresia, eles também estavam cobertos de sal.

Se Gomes estava no navio brasileiro Vencitore que naufragou na praia ao norte da vila de Ilhéus em setembro de I85I, sabe-se um pouco sobre a sua experiência. O navio era grande e apertadamente carregado, com entre 500 e 600 escravos, dependendo dos cálculos (BETHELL, I970, p. 358)..$^{15}$ As autoridades não podiam precisar exatamente de onde a viagem partiu, mas relataram que ele carregava cativos das etnias congo, quicongo e manicongo, uma clara indicação do comércio oriundo da parte central da costa ocidental da África. Do mesmo modo, dado que Luanda era um lugar onde se mantinham pessoas trazidas do interior, é possível que a viagem tenha se originado de lá. Ao menos alguns dos cativos do Vencitore eram, provavelmente, escravos luso-africanos cristãos. As autoridades interceptaram dois grandes carregamentos, em canoas, recuperando II2 dos cativos. Em que pesem as buscas extensivas na vila e nas fazendas próximas, não se encontrou vestígios dos outros 400 ou 500 escravos que se dizia estarem no navio (CRUZ, 2010, pp. I22-I27; MAHONY, 200I, pp. I03-IO4; BETHEL, I970, p. 358). No processo de busca por escravos de contrabando, no entanto, as autoridades encontraram um número de homens, mulheres e crianças, que eles descreveram como "ladinos" e "crioulos", presumivelmente com base em sua capacidade de falar português. ${ }^{16}$ João Gomes e outros como ele poderiam muito bem ter sido confundidos com escravos crioulos ou ladinos.

\footnotetext{
${ }^{14}$ APEB/SH. Juízes. Ilhéus, maço 2397. Joaquim Rodriguez de Sousa, Juiz de Direito ao Presidente da Província, I7 de fevereiro de I85I; Joaquim Rodriguez de Sousa, Juiz de Direito, à Presidente da Província, 30 de setembro de I85I; Ernano Dantas dos Santos, Juiz de Direito, ao Presidente da Província, I4 de abril de I856.

${ }^{15}$ APEB/SH. Rodriguez de Souza, ao Presidente da Província, 30 de setembro de I85I; www.slavevoyages.org, número da viagem no banco de dados 4785 .

${ }^{16}$ APEB/SJ. Rodriguez de Souza ao Presidente da Província, 30 de setembro de I85I.
} 
Em todo o caso, é provável que, onde quer Gomes tenha desembarcado pela primeira vez, ele estivesse em um grupo de cativos que incluíam africanos que falavam uma das línguas comuns na África central ocidental e também um pouco de português. Assim, um menino ou jovem que falava tanto português quanto uma ou duas línguas bantas poderia ser particularmente útil para os escravizados. Ele podia não só traduzir entre eles, como também conversar com os escravistas em nome deles. Relações desenvolvidas em tais circunstâncias teriam sobrevivido à travessia atlântica, especialmente se vários dos rapazes que sofreram juntos terminaram escravizados nas mesmas propriedades em Ilhéus.

\section{João Gomes em Ilhéus}

Gomes e os outros africanos que chegaram em Ilhéus no meio do século XIX juntaramse a uma comunidade bem pequena de escravizados. Apenas cerca de I.ooo pessoas escravizadas viviam em Ilhéus naquela época, cerca de vinte por cento da população total de menos de 6.00o pessoas. Mais da metade, ou até dois terços dessas pessoas escravizadas tinham nascido no Brasil e pouco mais da metade deles eram do sexo feminino, enquanto que, pelo menos, trinta por cento eram crianças com menos de io anos. ${ }^{17}$ Não causaria surpresa que muitos desses brasileiros escravos formassem famílias entre si, tanto nucleares quanto estendidas. Relativamente poucos foram capazes de viver juntos, porque apenas cerca de uma dúzia de plantações locais eram grandes o suficiente para ter mais de Io escravos, mas homens e mulheres escravizados eram, no entanto, capazes de formar conexões - embora não muito estáveis - para além dos limites das fazendas, nas plantações vizinhas. Poucos proprietários de escravos explicitamente admitiam possuir tais famílias, entretanto, documentos remanescentes indicam extensos laços de sangue e de parentesco entre escravos nascidos no Brasil nas plantações de Ilhéus, na segunda metade do século XIX (MAHONY, 2008, pp. 6409).

Proprietários de escravos e grande parte da historiografia sobre a escravidão no Brasil diriam que Gomes - e, na verdade, todos os africanos escravizados - teria tido muita dificuldade em se integrar a essa comunidade escravizada. Sabe-se bem que indivíduos africanos de diferentes origens étnicas tinham dificuldades de convívio entre si, bem como com os afrodescendentes nascidos no Brasil. De fato, um dos registros mais claros acerca

\footnotetext{
${ }^{17}$ Recenseamento de I872, 3:278.
} 
dessas dificuldades vem da Ilhéus do século XVIII, quando escravos nascidos no Brasil do Engenho Santana tentaram negociar um tratado de paz com o seu dono, que tinha escalado escravos minas da fazenda para tarefas que eles não queriam realizar (SCHWARTZ, I996, p. 6I). Entretanto, sugerir a existência de problemas semelhantes entre famílias e grupos de crianças e adolescentes escravizados que chegaram condições horríveis - e, em alguns casos, aterrorizados por um naufrágio - parece inadequado. Nas décadas de 1840 e I850, negros e negras africanos relativamente jovens estavam entrando em uma comunidade escravizada pequena, composta por um número relativamente pequeno de homens adultos, muitas mulheres adultas e um grande número de crianças. Em circunstâncias como essas, os africanos poderiam ter encontrado uma recepção mais calorosa entre os escravos já presentes do que diferentes grupos teriam encontrado em outras circunstâncias. Na verdade, é difícil imaginar que qualquer um dos escravos africanos ou brasileiros em Ilhéus não tivesse recebido os sobreviventes do naufrágio do Vencitore - que deviam estar exaustos mais atemorizados do que de costume - de qualquer modo que não fosse de braços abertos. Ao longo do tempo, certamente, os africanos e afrodescendentes brasileiros que viviam em Ilhéus desenvolveram relações importantes, muitas vezes laços entre pais e filhos.

Mais uma vez, João Gomes tinha qualidades específicas que teriam influenciado sua interação com as pessoas já escravizadas em Ilhéus. Como ele falava português, quicongo e, talvez, uma das línguas francas de Angola, ele teria pouca dificuldade em se comunicar tanto com escravos nascidos no Brasil quanto com "boçaes" da África ocidental central. Ele pode, portanto, ter servido como um mediador ou, pelo menos, como um tradutor entre os dois grupos, especialmente se os escravos nascidos no Brasil não fossem descendentes de africanos da parte ocidental central ou se viessem de famílias que tinham estado no Brasil há tanto tempo que já não falavam as línguas de seus antepassados africanos.

As noções de Gomes sobre família e liderança poderiam ter sido particularmente importantes em suas interações com as outras pessoas com quem compartilhou a experiência da travessia atlântica e/ou da escravização em Ilhéus. Se suas noções de família eram relacionais e dependentes da proximidade, então ele pode ter tido pouca dificuldade em considerar aqueles com quem partilhou o sofrimento como membros da sua família alargada, estivessem biologicamente relacionados a ele a partir do mesmo clã ou não. Por outro lado, tanto Gomes quanto os demais - se eles compartilhavam noções de liderança que enfatizavam a capacidade de resolver as coisas, ou para lidar com situações difíceis e confusas - podem tê- 
lo considerado como um trunfo para o grupo, o que deve ter facilitado sua integração, tanto com o grupo que já vivia na fazenda quanto com os recém-chegados.

Em seu depoimento às autoridades em I875, no entanto, Gomes afirmou que os outros escravos na fazenda onde vivia não gostavam dele. ${ }^{18}$ As autoridades pensaram que ele estava mentindo, mas devemos considerar a possibilidade de que ele estivesse dizendo a verdade, pelo menos da maneira que ele entendia. Se Gomes tinha sido criado na África portuguesa, com um sentimento de superioridade sobre outros africanos com menos familiaridade com os europeus ou com o cristianismo e o idioma português, ele pode ter se tornado persona non grata em Ilhéus. Se ele tratasse como inferiores essas pessoas já escravizadas em Ilhéus ou aquelas pessoas com quem cruzara o Atlântico e que não falavam português, ele poderia muito bem ter feito inimigos em vez de amigos.

\section{A vida na fazenda Santo Antônio da Ribeira das Pedras}

Gomes acabou escravizado em uma das poucas grandes propriedades na região, Santo Antônio da Ribeira das Pedras. O dono da fazenda, Fortunato Pereira Gallo, era um proprietário incomum para Ilhéus, se não para a Bahia. O segundo filho de uma família portuguesa de elite, proprietária de engenhos na região produtora de açúcar do Recôncavo da Bahia, ele foi educado na Europa e, provavelmente, nunca imaginou que viveria em uma pequena cidade fronteiriça como Ilhéus. Em I830, no entanto, seu pai faleceu, deixando a propriedade do Recôncavo para ser dividida entre vários irmãos e membros da família estendida. Em vez de dividir a herança, o herdeiro mais velho, Domingos, comprou o interesse dos seus irmãos mais novos. Fortunato, como o segundo mais velho, tomou sua parte em escravos, dinheiro e crédito e, em I848, mudou-se para Ilhéus com o seu irmão mais novo Manuel e começou a transformar três extensas, porém subdesenvolvidas áreas em uma grande fazenda. ${ }^{19}$

Vinte e oito anos depois, em I876, Gallo descreveu uma propriedade impressionante, quando fez o seu testamento. A fazenda media I.50o hectares de terra e produzia açúcar, madeira e algum cacau. Grande parte da propriedade era coberta por mata, mas os moinhos

\footnotetext{
${ }^{\mathrm{I} 8} \mathrm{APEB} / \mathrm{SJ}$. Processo-crime No 2I/748/9, ff.67f-68v.

${ }^{19}$ Para reconstruir a história da família Gallo, ver APEB/SJ, Inventário No. 3/1356/I825/2I, Fortunato Pereira Gallo, São Francisco do Conde, I830-I846; Testamento No. 5/2189/2658/55, I876, Fortunato Pereira Gallo, Salvador, I876; Inventário No. 7/3159/4, Eudolfe Pereira Gallo e Rosenda Pereira Gallo, I867-I873, Salvador; APEB/SH Joaquim Rodrigues de Sousa, juiz de direito de Ilhéus à presidente da província, 8 janeiro I85I, maço 2397.
} 
movido a água para processar madeira e cana-de-açúcar eram os equipamentos mais modernos na região. A força de trabalho da fazenda incluía, pelo menos, 65 escravos. Cerca de metade desses trabalhadores escravizados eram mulheres e um quarto eram crianças com menos de 12 anos. ${ }^{20}$ A composição de sua força de trabalho explica por que os trabalhadores em sua propriedade passaram a maior parte da década de I870 plantando cacau, de tal modo que, em I88I, a propriedade era uma das duas maiores fazendas de cacau em Ilhéus, com cerca de 200.000 pés (AGUIAR, I979, p. 266).

Gomes disse às autoridades que ele era oleiro e agricultor. Este relatório, junto a uma breve descrição da fazenda contida nos documentos, torna possível reconstruir parte significativa da sua vida de trabalho na escravidão. Santo Antônio da Ribeira das Pedras era localizada na Mata Atlântica, em uma área coberta por floresta de crescimento primário e secundário. A área era acidentada, com uma mistura de solo arenoso e argiloso. Qualquer plantio que fosse feita, portanto, necessitava primeiro da limpeza das plantas e arbustos menores ou florestas primárias, trabalho árduo em quaisquer condições. Plantio, capina e colheita de cana-de-açúcar era complicada pelas colinas baixas, porém íngremes, do terreno local, do qual uma pequena parte era plana. Os trabalhadores tinham de subir e descer as colinas para cortar cana, uma tarefa difícil mesmo quando a terra era plana. A partir dessa perspectiva, o plantio de cacau era mais fácil, mas é improvável que Gomes e os outros homens da fazenda estivessem muito envolvidos com o cacau. A maioria dos plantadores estavam investindo em cacau, por não ter a força de trabalho necessária para a cultura da cana. As mulheres, crianças e idosos escravizados em suas propriedades, assim, trabalhavam plantando cacau, enquanto os homens trabalhavam com madeira e açúcar (MAHONY, 20I6, pp. 3-9). De fato, a presença de um grande número de mulheres e crianças na força de trabalho da Ilhéus do século XIX foi um dos os incentivos para o plantio de cacau (ALMEIDA, I904, s/p). O trabalho agrícola escravo nunca era divertido, mas a vida na fazenda de Gallo era provavelmente tão difícil quanto em qualquer outra fazenda no Brasil, talvez porque seu proprietário tinha aprendido seu estilo de gestão no engenho do Recôncavo, onde ele cresceu. Ao ser entrevistado pelas autoridades, Gomes reclamou que Gallo privava seus trabalhadores de necessidades básicas - presumivelmente, comida - e os punia injustamente. ${ }^{2 I}$ Donos de

\footnotetext{
${ }^{20}$ Classificação dos escravos.

${ }^{2 I}$ APEB/SJ. Processo-crime No. 2I/748/9, Ff. 38f-38v.
} 
escravos acreditavam que todos os escravos faziam esse tipo de queixa, mas há indicações de as queixas de Gomes eram verdadeiras.

Grande parte da evidência destes maus-tratos é indireta, baseadas em sugestões de que os irmãos ofenderam a todas as camadas sociais do município, não só pessoas escravizadas. Os irmãos Gallo criaram muitos inimigos na sociedade local, livres e escravizados; membros da elite e membros do povo. Pesquisando violência de donos de escravos no sul dos Estados Unidos, o historiador Schweninger constatou que os homens que abusavam suas esposas, filhos e filhas também maltratavam seus escravos e vice-versa (SCHWENIGER, 200o, pp. 3335). Esta pesquisa oferece pistas interessantes para refletir sobre o comportamento dos donos do Engenho Santo Antônio da Ribeira das Pedras.

Três anos depois de chegar em Ilhéus, Fortunato e Manuel Pereira Gallo tinham ganhado a inimizade de pessoas da cidade, em todos os níveis. Em janeiro de I85I, o Juiz de Direito relatou a seus superiores em Salvador que os proprietários locais estavam reclamando dos dois irmãos. Eles estavam, disseram-lhe, comportando-se como valentões, disparando armas e insultando todos quando estavam bêbados. ${ }^{22}$ Eles e um grupo de homens armados atacaram a fazenda de Joaquim Pedro Scola, um bem respeitado imigrante italiano de cerca de 50 anos de idade, que era casado e tinha duas filhas. Junto com outro jovem da elite local, Manueltinha provocado uma grande briga durante as festividades de Reis de I85I, quando eles tentaram entrar em uma festa na casa de pessoas "comuns" da cidade. O juiz não explicitou sobre o que causou a briga, informando apenas que os dois jovens da elite tentaram entrar à força na festa e provocaram os as pessoas que dançavam, a ponto de serem expulsos, tendo as pessoas batido neles e tentado esfaqueá-los. Parece que os dois jovens teriam violado as normas locais de comportamento nas festas. O juiz informou a seus superiores que o problema residiria na hostilidade dos moradores locais para com recém-chegados, mas é improvável que esta tenha sido a história inteira. Lendo nas entrelinhas, a referência à provocação das pessoas dançando sugere algum tipo de mau comportamento com as senhoras e moças no evento. ${ }^{23}$

A hostilidade local para com os recém-chegados, porém, parece uma razão improvável para os problemas que os irmãos Gallo estavam tendo. Ilhéus foi objeto de significativa especulação de terras na primeira metade do século XIX e os estrangeiros e brasileiros de outras partes da Bahia eram muitos entre a elite local. Joaquim Pedro Scola, o proprietário de

\footnotetext{
${ }^{22} \mathrm{APEB} / \mathrm{SH}$. Rodrigues de Sousa à presidente da província, 8 de janeiro de I85I.

${ }^{23} \mathrm{APEB} / \mathrm{SH}$ : Rodrigues de Sousa à presidente da província, 8 de janeiro de I85I.
} 
uma fazenda que Gallo supostamente teria atacado, era um imigrante italiano muito respeitado, proprietário da fazenda Ermo Nobre e sua família estava em Ilhéus por menos de vinte anos na época do problema com os Gallo. Da mesma forma, inúmeros vizinhos de Gallo ao longo do Itaípe, incluindo os Lavignes, os Sás e os Homem del Reis, tinham chegado a Ilhéus nas duas décadas anteriores. Embora possa ter sido verdade que os moradores mais antigos e os recém-chegados encontrassem dificuldades para se relacionar, pelo menos alguns dos problemas de Gallo eram, na verdade, com outros recém-chegados, não com os residentes de longa data.

Os irmãos parecem ter pouco senso de um comportamento adequado, em uma comunidade aonde quase tudo mundo era, nos olhos deles, de status mais baixo. Como homens criados num engenho de cana de açúcar no Recôncavo, eles ocupavam o auge da hierarquia social da Bahia. No mundo deles, sua posição dera-os direitos senhoriais na sociedade local. Pode ser que entre estes direitos, deve-se incluir acesso as filhas das famílias locais. Esta possibilidade ajuda o entendimento dos problemas entre eles e os residentes locais. Joaquim Pedro Scola não era apenas um grande proprietário de terras, ele era também o pai de duas filhas de ascendência ítalo-francesa, nascidas em Paris, onde Fortunato e Manuel tinham sido educados. Talvez os dois irmãos lhes tivessem dado certo tipo de atenção que seu pai considerou inadequada fora do casamento, ou mesmo dentro, dada a propensão dos irmãos para o álcool e a violência. A briga no baile poderia ter sido originada por problemas semelhantes, com homens locais sobre o tratamento dispensado às mulheres. Seguramente, um homem branco, da elite tradicional baiana, bêbado e valentão em uma festa envolvendo os moradores locais, a maioria dos quais teriam ascendência africana ou indígena, pode se comportar de várias maneiras interpretadas como ofensivas. Assediar as mulheres presentes poderia ter sido, certamente, uma delas.

Os problemas com vizinhos começaram antes dos irmãos chegar em Ilhéus. Manuel foi assassinado por tiros em I852, de acordo com rumor local, por um pistoleiro enviado por um inimigo do Recôncavo de sua cidade natal. ${ }^{24} \mathrm{O}$ porquê de ele ter criado tal inimizade não é claro, mas ele deixou um filho natural vivendo na fazenda de seu irmão em I852. Tal tipo de vingança leva sugestões de uma ofensa a honra duma família poderosa. Talvez ele também tenha importunado uma menina de status alto no Recôncavo. Um senso de responsabilidade

\footnotetext{
${ }^{24}$ APEB/SJ, APEB/SH, Joaquim Rodrigues de Sousa, maço 2397, juiz de direito de Ilhéus à presidente da província, ? I852.
} 
para com a honra feminina é, certamente, uma das razões pela qual um inimigo do Recôncavo poderia ter mandado um jagunço as matas do sul da Bahia matar Manuel Gallo.

Fortunato Gallo continuou a ter problemas depois que Manuel morreu. Em I864, Paulino e Francisco Cândido dos Passos invadiram a casa do Fortunato em Ilhéus, ameaçando-o com uma faca. O proprietário começou a chamar socorro, mas os vizinhos demoraram a responder, porque, segundo uma testemunha, era comum ouvir gritos e vozes altas da casa dele. A investigação do caso revelou que os problemas entre Gallo e os irmãos começaram quando o proprietário negou pagar Francisco pelos cinco anos que ele funcionou como administrator do Engenho Santo Antônio. Os irmãos Passos foram presos e acusados de tentativa de homicídio, mas as acusações contra eles foram retiradas, porque nenhuma das testemunhas admitiu ter ouvido eles ameaçarem matar Gallo. A inabilidade das autoridades em punir um ataque a um dos maiores agricultores da região sugere que a simpatia do público não estava com Gallo. ${ }^{25}$

Voltando às pesquisas de Loren Schweninger, suponhamos que os tratamentos que os irmãos Gallo dava aos seus cativos seguiram o padrão do comportamento dos irmãos em público. Donos de escravos dados para a violência pública, que não tinham escrúpulos ao maltratar empregados livres nem vizinhos de status social equivalente, teriam tido poucos escrúpulos no tratamento de seus cativos. Sabemos que os irmãos Gallo eram negligentes com suas obrigações financeiras, andavam bêbados, entravam em brigas e assediavam mulheres pertencentes à comunidade livre local, inclusive da elite, então não é acreditável que tratassem os homens, mulheres e crianças que possuíam com cuidado e preocupação.

Só temos as palavras de João Gomes às autoridades sobre a falta de comida e a punição em Santo Antônio da Ribeira das Pedras, mas há ampla evidência de que Fortunato Pereira Gallo usava suas escravas sexualmente. Quando ele fez o seu testamento após o atentado de I875, Gallo afirmou que, desde a morte de sua esposa, ele não tinha tido filhos que fosse obrigado a reconhecer. ${ }^{26}$ Em outras palavras, ele tinha tido filhos, mas não legítimos. Ele então passou a conceder legados a uma amante e quatro ou cinco crianças, nascidas de, pelo menos, três mulheres diferentes, duas das quais eram claramente suas escravas. Os filhos incluíam Apollo, nascido na década de I860, com a negra escravizado Luiza; Delmira, cuja condição

\footnotetext{
${ }^{25}$ APEB/SJ. Processo-crime No 22/784/05. Tentativa de Homicídio, Réus, Paulino Candido dos Passos e um outro, 22 junho I864.

${ }^{26}$ FÓRUM EPAMINONDAS BERBERT DE CASTRO. POVC. Registro de autuação de uma petição de Fortunato Fausto Gallo e registro de testamento do pai, I3 junho I876, Registro de testamentos, Ilhéus, vários escrivães, I847I939.
} 
jurídica não era clara, foi a mãe de uma menina, Serafina, a quem ele deixou um legado. Olegária, uma doméstica escravizada em Santo António da Ribeira das Pedras, foi mãe de dois filhos - Constança e Terêncio. Terêncio foi batizado livre e recebeu sobrenomes do pai. A mãe deles tinha I6 anos quando deu à luz ao primeiro filho de Gallo e I8, quando ela deu à luz ao segundo. Outro filho ilegítimo, Solon Constantino Gallo, de cuja mãe o nome não aparece nos documentos, estava supervisionando o trabalho feito na fazenda com seu pai quando atiraram nele. ${ }^{27}$

Outra liberta de Ilhéus pode ter sido a filha de um dos irmãos Gallo. Quando chegaram em Ilhéus, os irmãos trouxeram com eles uma mulher escravizada chamado Efigênia e sua filha Maria das Virgens Gallo. Maria das Virgens nasceu por volta de I840 em São Francisco do Conde, quando Fortunato tinha alguns 20 anos e Manuel era um pouco mais jovem. Se ela foi batizada como livre não fica claro, mas ela estava livre em i860 quando se casou com Manuel Félix Pitombo, um homem mulato livre de Pernambuco e se mudou para um pedaço de terra vizinho que eles transformaram em uma próspera fazenda de cacau. ${ }^{28} \mathrm{~A}$ evidência de sua paternidade é circunstancial, mas sua experiência é semelhante à de várias crianças mais jovens a quem Gallo deixou a liberdade e um pequeno legado.

Dado o histórico de atividade sexual na senzala de Fortunato Gallo, aliado ao comportamento irresponsável e agressivo para com seus vizinhos, não é de surpreender que, em I873, alguém tentasse matá-lo. Quando entrevistado sobre o evento, ele negou ter feito qualquer coisa que faria qualquer um querer matá-lo, uma declaração extraordinária dada a sua história, mas rumores locais sugeriam que qualquer um de seus vizinhos ou seus escravos podiam estar por trás do ataque. Os escravos tinham a expectativa de serem libertados, diziase, por causa de uma ação judicial sobre direitos de herança que Gallo tinha sido forçado a responder em Salvador. $\mathrm{O}$ ataque tinha ocorrido na noite em que o fazendeiro havia retornado à Ilhéus vitorioso. No dia seguinte, no entanto, um novo boato começou a circular que um fazendeiro de nome José Antônio Guimarães Bastos teria mandado seu escravo Joaquim atirar em Gallo, por causa de uma velha desavença. ${ }^{29}$ A questão nunca foi definitivamente resolvida.

\footnotetext{
${ }^{27}$ Testamento No 02/750/I2I6/02.

${ }^{28}$ ARQUIVO DA CÚRIA DE ILHÉUS. Livro de Batismos I870-I876. Danificado; FEBC/POVC, Registro de testamentos, Ilhéus; APEB/SJ, Testamento No. 02/750/I2I6/02. Salvador. Em I840, Fortunato Gallo obteve a tutela de seus irmãos e irmãs mais novos, e, portanto, teria, pelo menos, 2I anos de idade.

${ }^{29}$ APEB/SH. Antônio Gomes Vilhaça juiz de direito de Ilhéus à vice-presidente da província, I8 de julho de I873; Antônio Gomes Vilhaça juiz de direito de Ilhéus à vice-presidente da província, I9 July I873, maço 2402; APEB/SJ, Inventário No 7/3159/4.
} 
Mais uma vez, as autoridades locais não tomaram providências contra pessoas que se acreditava terem atentado contra a vida do proprietário de Santo Antônio da Ribeira das Pedras.

\section{João Gomes como quilombola}

Muitas pessoas, certamente, continuaram a acreditar que os escravos de Gallo estavam por trás do ataque. Pelo menos um, Aprígio, de 22 anos de idade, foi interrogado no contexto da investigação do atentado. Certamente, alguns dos homens escravizados em Santo Antônio estavam particularmente descontentes: em julho ou agosto de I873, muitos deles fugiram. No final daquele ano, sete tinham escapado, de três fazendas diferentes e tinham estabelecido um quilombo na floresta entre Ilhéus e Barra do Rio de Contas (atualmente, Itacaré).

Assim como outros quilombolas no Brasil, o grupo permaneceu nos arredores das propriedades onde tinham sido escravizados. O Quilombo da Lagoa, como as autoridades o apelidaram, não era diferente. $\mathrm{Na}$ verdade, haviam dois locais, um para os fugitivos mais velhos e outro, para os mais jovens. Como argumentaram persuasivamente Stuart Schwartz, João Reis e Flávio Gomes, a maioria dos quilombos eram pequenos e localizados nas proximidades das fazendas de onde tinham fugido seus integrantes. Palmares, em outras palavras, era a exceção e não a regra (REIS, 2000, p. 332; SCHWARTZ, I996, p. IO6-IO7).

Durante os dois anos e meio que se seguiram, o grupo tinha construído duas pequenas cabanas, plantava feijão, milho e mandioca, armazenava piaçava e vendia a sua produção na vila da Barra do Rio de Contas, onde conseguiram comprar, pelo menos, uma arma de fogo. Os negócios entre os quilombolas e comerciantes locais não causa surpresa, pois, como João Reis descobriu, fazendeiros rivais da região, desesperados por mão de obra, faziam vista grossa para o status legal de trabalhadores negros no início do século XIX (REIS, 200o, p. 332). De fato, o comércio que os quilombolas mais recentes desenvolviam sugere que a Barra do Rio de Contas continuava a ser um lugar onde escravos fugitivos podiam ter a segurança de que os fazendeiros e comerciantes locais não iriam entregá-los às autoridades de Ilhéus. O Quilombo da Lagoa parece ter tido pouca prioridade para os funcionários locais, até que alguém cometeu 
um novo atentado contra a vida de Gallo, quando as autoridades locais pediram auxílio e o governador da província enviou uma milícia para destruir o quilombo. ${ }^{30}$

Os fugitivos incluíam agricultores e trabalhadores com outras habilidades. Gomes sabia fazer tijolos e também era agricultor. Ele também relatou ter trabalhado na enfermaria da fazenda. Entre os outros quilombolas, havia um carpinteiro, um pedreiro na casa dos 40 anos e quatro trabalhadores agrícolas. ${ }^{3 \mathrm{I}}$ Os três homens que tinham habilidades de construção, possivelmente, se conheceram quando Gallo os alugou a outros fazendeiros, que precisavam desse tipo de mão de obra qualificada. A visita a outras propriedades pode ter dado a eles a oportunidade de discutir os problemas que tinham com seus donos e com Gallo.

Os quilombolas eram todos homens, quatro deles na casa dos 20 anos e três entre 40 e 60. A diferença geracional entre os fugitivos é sugestiva. Eles se dividiam em dois grupos distintos: um de homens mais velhos e outro, de homens mais jovens. Os mais velhos tinham, todos, idade suficiente para ter chegado em Ilhéus na época em que os Gallo adquiriram sua fazenda, 28 anos antes. Alguns podem ter integrado a herança de Gallo, enquanto outros, como Gomes, fizeram a jornada da África para Ilhéus enquanto crianças ou jovens adultos. Os mais jovens, por sua vez, nasceram depois que os Gallo compraram a fazenda Santo Antônio. Eles, seguramente, nasceram em Ilhéus e não é impossível que um ou mais deles fossem filhos biológicos dos mais velhos. Conforme se argumenta acima, no entanto, Gomes viveu seus primeiros anos em uma sociedade que não exigia laços biológicos para definir o parentesco. Os jovens e os velhos tinham passado, pelo menos, 20 anos juntos na escravidão, tendo os mais velhos visto os outros crescer, enquanto os mais novos aprenderam com eles sobre o trabalho e a sobrevivência à escravidão. Ainda que houvesse diferenças culturais, os laços entre eles eram significativos.

Os homens também tinham ligações próximas com as mulheres na fazenda de Gallo. Conforme argumentado no início, os homens, mulheres e crianças escravizados em Ilhéus foram capazes de formar famílias, embora raramente legalizadas ou abençoadas pela Igreja Católica. É mais fácil investigar as conexões entre mulheres e crianças nessas relações do que entre homens e suas parceiras ou filhos, mas documentos de Ilhéus indicam que tais relações existiam. Infelizmente, os laços entre os homens, mulheres e crianças das fazendas dos Gallo e

\footnotetext{
30 APEB/SH: Antônio Gomes Vilhaça à vice-presidente da província, I8 julho I873.

${ }^{3 \mathrm{I}}$ Processo Crime, No. 2I/748/9, f. I2-I5, f. I8, f. 38-40.
} 
dos Lavigne não estão claramente documentados, mas as evidências circunstanciais sugerem que eles existiam.

Os quatro homens mais jovens no quilombo tinham a mesma idade das mulheres que receberam legados no testamento de Gallo. Quando ele registrou os indivíduos escravizados de sua propriedade no Fundo de Emancipação, ele listou seis jovens mulheres entre I9 e 2I anos. Luís Gaston Lavigne elencou outras quatro jovens mulheres da mesma idade. ${ }^{32}$ Todas elas tinham idade de serem irmãs, amigas de infância ou parceiras românticas dos homens jovens no quilombo, ou filhas dos mais velhos. Seguramente, passaram décadas juntos na escravidão.

As relações entre todos esses homens e mulheres não precisavam ser biológicas para serem importantes. Gomes, conforme já foi dito, nasceu em uma sociedade onde as noções de família eram relacionais. Irmão, irmã, mãe e pai não necessariamente se referem a pessoas às quais ele estava ligado pelo sangue. Se ele tivesse cruzado o Atlântico com qualquer dos homens ou mulheres mais velhos das fazendas de Gallo ou Lavigne, visto os jovens crescer na escravidão, trabalhado e sofrendo junto com jovens e velhos, ele - assim como os demais teria os teria enxergado como parentes. Depois de quase 30 anos em uma fazenda e em uma região, com mais mulheres do que homens escravizados - e um grande número de crianças as relações formadas seriam bastante complexas (MAHONY, 2008, pp. 633-666; 2015, pp. 295329).

É neste contexto que temos de olhar para o testemunho de Gomes e responder às questões que ele levanta. Será que ele atirou em Gallo num acesso de raiva? Ou o fizeram Aprígio, Antônio e Augusto, como Gallo inicialmente alegou? Gomes teria sido parte de uma conspiração de escravos fugitivos para matar o fazendeiro? Teriam os outros moradores do quilombo forçado Gomes a se entregar às autoridades? Teria ele se voluntariado à rendição?

\section{João Gomes e a resistência negociada à escravidão em Ilhéus}

Não se pode dizer, de modo definitivo, qual das possibilidades oferece a interpretação mais correta acerca do envolvimento João Gomes nos eventos abril de I875 em Ilhéus, mas o retorno à questão sobre sua identidade pode oferecer alguma pista para linhas de interpretação mais frutíferas. Gomes, sendo um homem com noções relacionais sobre o

\footnotetext{
${ }^{32}$ APEB/SH, Classificação dos escravos.
} 
parentesco e tendo passado mais de vinte anos vivendo e trabalhando em Santo Antônio da Ribeira das Pedras, deve ter desenvolvido laços estreitos com, pelo menos, algumas das pessoas com quem compartilhou a escravização. Ele, certamente, deve ter compartilhado um sentimento de sofrimento comum com eles e, também seguramente, não gozava da confiança de Gallo. Em I864, houve um homem, chamado Adolfo, que foi acusado de atirar em alguém a mando de Gallo.

Gomes, definitivamente, deve ter sofrido sofreu uma severa punição, provavelmente uma surra e chicotadas, como resultado de seu pedido para ser vendido. Sua experiência, porém, não foi singular. Gallo tratava mal a seus vizinhos, em outras palavras, seus pares locais. Não há, absolutamente, nenhuma razão para acreditar que sua personalidade mudava quando se lidava com os cativos em sua propriedade. Na verdade, seu comportamento era provavelmente pior. Fortunato Gallo, como seu irmão antes dele, parece que tinha um temperamento desagradável. Muitos cativos na propriedade Gallo podem ter sofrido espancamentos.

Gomes certamente tinha laços de parentesco fictício estabelecidos na propriedade e, talvez, laços de parentesco biológico. Em I874, vinte dos escravos na plantação eram mulheres adultas e outras treze eram filhos menores dessas mulheres. A fazenda não tinha a proporção equilibrada entre homens e mulheres como alguns de seus vizinhos, porém várias outras fazendas da região eram, predominantemente, compostas por mulheres escravizadas e seus filhos, alguns dos quais poderiam ter sido os filhos dos homens escravizados na propriedade (MAHONY, 2008, pp. 633-666; 200I, pp. 195-I39). De fato, dada a prevalência de famílias escravizadas em Ilhéus, a composição do Quilombo da Lagoa sugere que os homens que o ocuparam eram pais e filhos, pelo menos simbolicamente, se não biologicamente.

Tal grupo de homens deve, certamente, como indivíduos e como grupo, ter tido relações de vários níveis com as mulheres nas propriedades em que elas e eles viviam. Nestas mulheres os homens da Lagoa Quilombo teriam encontrado mães, filhas, irmãs, amantes e amigas. Não está fora do espectro de possibilidades, portanto, de que o ataque de i875 contra Gallo - e, talvez, até mesmo o de I873 - tenha surgido a partir de uma decisão coletiva, por parte dos homens escravizados da área, para colocar um fim a todo o seu comportamento repreensível, incluídas as suas atividades sexuais nas senzalas.

Não é surpreendente que nem os autos do processo contra Gomes, nem a correspondência entre as autoridades em I873 ou I875 contenham qualquer indício de que 
Gallo se comportara de forma inadequada com relação às mulheres escravizadas em sua propriedade. Os legados descritos em seu testamento, junto com sua afirmação de que ele era pai de filhos, mas não filhos legítimos, indica que ele acreditava que tinha o direito aos favores sexuais das mulheres escravizadas em sua propriedade. Enquanto muitos problemas poderiam explicar o atentado de 1873 sobre ele, a segunda gravidez de Olegária certamente deve ser incluída entre eles. Talvez, por volta de I875, os homens nas propriedades de Gallo e de Lavigne tivessem simplesmente dado um basta a este homem, cujo comportamento violava todas as regras sociais aceitáveis, pelo menos quando ele bebia.

Se uma tentativa de acertar as contas com Gallo ou para parar o seu comportamento assediante nas senzalas de Santo António da Ribeira estivesse por trás das tentativas de matálo em I873 e I875, por consequência, os homens do Quilombo da Lagoa teriam dado mais um exemplo das maneiras pelas quais a solidariedade entre os escravos, como Stuart Schwartz argumentou persuasivamente, poderia residir em "objetivos comuns [e] objeções específicas para com aqueles que administravam a propriedade [...] e sobre em sua insatisfação com aspectos específicos do regime de trabalho (SCHWARTZ, I996, p. 53). Tais relações poderiam, até mesmo, desenvolver-se entre inimigos históricos, como João Reis demonstra, de forma convincente, em seu estudo sobre a Revolta dos Malês em Salvador (REIS, 2003).

A solidariedade, no entanto, não significa necessariamente que Gomes puxou o gatilho da arma com a qual Gallo foi baleado. Pode-se facilmente imaginar um grupo de escravos fugitivos elaborando uma estratégia para, em primeiro lugar, parar Gallo e, em seguida, gerir a situação. Alternativamente, eles podem ter se sentado para tentar decidir a melhor forma de proteger a todos, depois de um deles, inesperadamente, ter tentado matar o fazendeiro. $\mathrm{O}$ atirador pode ter sido Gomes, mas também pode ter sido Aprígio, como Gallo apontou a princípio. De fato, nas horas e dias imediatamente posteriores ao ataque, Gallo relatou ter visto Aprígio - um jovem de cerca de 23 anos - e outro jovem negro, em pé com um rifle, debaixo de uma árvore, pouco antes de ele ouvir o tiro. Gallo disse, mais tarde, que ele não tinha certeza do que viu, mas os jovens se enquadram mais no perfil dos escravos que atacavam seus proprietários mais do que Gomes. Escravos mais jovens eram muito mais propensos a reagir violentamente contra seus donos do que os mais velhos, ou mesmo idosos, como João Gomes. Depois de quase 30 anos de vida adulta, trabalhando em Santo Antônio das Pedras, Gomes certamente tinha muita experiência em tolerar o comportamento de Gallo. Aprígio e os outros homens mais jovens tinham sido criados em contato com esse 
comportamento, mas era menos provável que eles estivessem dispostos a tolerá-lo. Se eles tivessem criado laços com colegas do sexo feminino que atraíam a atenção de Gallo, eles podem ter tido motivos particulares para tentar um acerto de contas. Se Gallo tivesse tido relações sexuais com uma mulher próxima de Aprígio, então ele pode ter sido o homem que puxou o gatilho em um acesso de raiva. Gallo certamente acreditava que o escravo mais novo estava por trás do ataque.

Nesse ponto, compreender as noções de liderança de Gomes pode ser particularmente útil no esclarecimento da situação. Conforme argumentado anteriormente, tais conceitos, para ele, eram relacionais e dependiam da situação em que se encontrava. Se ele e os outros no quilombo acreditavam que liderança envolvida, não chefia hereditária, mas sim a responsabilidade para com as pessoas, a capacidade de entender como as coisas funcionavam, ou o que deveria ser feito, ou como uma determinada situação deve ser gerida, ele poderia ter confessado um crime que não cometeu, a fim de proteger os outros.

Para tal estratégia, teria sido crucial a avaliação do grupo de que Gomes era o mais capacitado para manipular as autoridades. Como um escravo luso-africano mais velho que falava bem português, que acreditava entender os portugueses e o seu sistema de escravidão e que partiu do pressuposto que a sua punição seria a venda para longe de Ilhéus, ele pode ter se considerado o homem mais adequado para lidar com a situação. Mesmo não querendo deixar amigos e família para trás, ele pode muito bem ter acreditado que se render era sua responsabilidade e que, ao fazê-lo ele salvaria os outros de tal destino.

Por outro lado, não podemos descartar completamente a declaração de Gomes de que ele agiu sozinho e sem premeditação. A fazenda de Gallo era um lugar particularmente desagradável para sofrer a escravidão. Gomes, portanto, poderia ter passado a acreditar que Gallo tinha arruinado a sua vida por qualquer número de razões e tentou manipular o sistema legal para ficar longe daquele proprietário horrível, naquele lugar desagradável. Ele certamente estava ciente de que se poderia ser escravizado em circunstâncias muito variadas.

No entanto, um homem como Gallo certamente sabia o suficiente sobre o que os portugueses e seus descendentes brasileiros pensavam de si mesmos e seus escravos para ser capaz de manipulá-los. Ele sabia que eles pensavam que o seu sistema judicial e seu Deus eram justos. Ele também sabia que eles viam Ilhéus como um lugar ermo e que viver em cabanas na floresta era viver como animais selvagens. Ele também sabia que eles acreditavam que vários grupos de africanos e escravos brasileiros, frequentemente, não se davam muito 
bem. No mínimo, ele teria ouvido isso através das barras de sua cela, enquanto os curiosos locais paravam para vê-lo acorrentado em uma casa no porto, que inundava toda vez que chovia e quando a maré estava particularmente alta. Ele acreditava saber que eles iriam vendêlo, não matá-lo, um escravo que atacou um proprietário em um momento em que a mão de obra era escassa. Ele estava errado, neste caso, eles o levaram a julgamento por sua vida. Só então, ele voltou atrás da confissão de ter atacado Gallo, mas mesmo assim não culpou mais ninguém.

\section{Conclusões}

O que aconteceu, finalmente, com João Gomes não fica totalmente claro. Em que pese o fato de que Gallo tinha originalmente identificado Aprígio como seu agressor, as autoridades decidiram aceitar a confissão do escravo mais velho. Eles o acusaram de tentativa de assassinato, uma acusação que, caso confirmada, seria punida com a pena de morte. Quando ouviu as acusações oficiais contra ele, Gomes retratou-se da sua confissão, afirmando que havia confessado em um esforço calculado para fazer o seu proprietário vendê-lo. Se ele se ofereceu para sacrificar-se pelos outros no quilombo, havia limites para sua compreensão de solidariedade e responsabilidade. A fim de convencer as autoridades de suas histórias, ele disse aquilo em que pensava que as autoridades acreditariam. Ele afirmou ter tinha confessado tentar matar Gallo por não poder mais tolerar viver na floresta, como um animal selvagem. Ele foi adiante, relatando hostilidade entre ele e os outros quilombolas e, na verdade, todos os moradores escravos das fazendas locais. Ele disse que seus parceiros não gostavam dele e que eles mentiam sobre ele. Gomes pode muito bem ter detestado a vida na floresta, afinal, seus primeiros anos de vida foram vividos em uma cidade e ele tinha sofrido a escravidão brasileira em uma propriedade com cerca de 80 outras pessoas. Porém, é improvável que ele e os outros quilombolas não confiassem uns nos outros, pelo menos um pouco. Eles tinham compartilhado uma vida juntos em liberdade - ou, ao menos, uma versão mediada e frágil da liberdade - no quilombo por mais de dois anos. Essa experiência sugere um nível de confiança mútua que não comporta o argumento de que ele e os outros quilombolas não gostam um do outro. Diferenças entre si, eles certamente devem ter tido, mas uma total desconfiança e antipatia mútua - como Gomes tentou sugerir - não se encaixam nas evidências. As autoridades tampouco acreditaram nele. 
As autoridades não queriam acreditar na confissão Gomes no início, mas, depois, não queriam acreditar na sua inocência. Aparentemente, uma vez que havia um bode expiatório para punir, pouco lhes importava se ele tinha realmente puxado ou não o gatilho da arma com a qual Gallo foi baleado. A idade de Gomes provavelmente ajudou convencê-los: contando entre 40 e 60 anos, o homem estava no fim de sua vida laboral, enquanto Aprígio e os outros jovens no quilombo tinham muitos anos de trabalho, em potencial, para fornecer, em um lugar onde havia escassez de mão de obra. Um júri composto por donos de escravos, seus parentes e empregados o condenaram por tentativa premeditada de matar alguém, com o agravante da premeditação, sentenciando-o à morte em 27 de julho de I875. Uma vez que a pena foi imposta, Gallo abdicou por escrito de quaisquer direitos sobre Gomes e, depois, conforme requerido, a sentença foi objeto de apelação para o Imperador no Rio de Janeiro. Em sua defesa, a Princesa Isabel reformou a sentença de Gomes para prisão com trabalho por 20 anos. $^{33}$ Gomes, em seguida, desaparece dos registros.

Embora não possamos saber se João Gomes realmente tentou matar seu dono Fortunato Pereira Gallo, ou se ele agiu sozinho ou como parte de uma conspiração, colocá-lo no contexto do Mundo Atlântico nos permite reconstruir sua vida, desde sua infância na África até o seu transporte para o Brasil e suas experiências na fazenda de Gallo, em Ilhéus. Assim o fazendo, o transforma em uma pessoa real, em vez de uma incógnita e nos traz cada vez mais perto de ver as complexidades dos seres humanos que cruzaram o oceano a partir de África para o Brasil nos porões dos navios negreiros. Isso, por sua vez, nos permite explorar as possibilidades por trás das declarações e experiências de Gomes, que turvam as linhas anteriormente claras entre os escravos brasileiros e africanos e esclarecer as circunstâncias em que eles foram capazes de desenvolver a solidariedade.

\section{Referências bibliográficas}

AGUIAR, Durval Vieira. Descrições práticas da província da Bahia: com declaração de todas as distâncias intermediárias das cidades, vilas e povoações. Prefácio de Fernando Sales. 2. ed. Rio de Janeiro: Livraria Editora Cátedra em convênio com o Instituto Nacional do Livro, Ministério da Educação e Cultura, Brasília, 1979.

\footnotetext{
${ }^{33}$ APEB/SJ, Processo-crime No. 2I/748/9, Ff. 86f-87v.
} 
ALENCASTRO, Luis Felipe. O trato dos viventes: formação do Brasil no Atlântico Sul. São Paulo: Companhia das Letras, 2000.

ALMEIDA, Miguel Calmon du Pin e. Memôria sobre a Cultura do Cacau. Reimpresso do Jornal da Sociedade d'Agricultura da Bahia. vol. 4. I836. In: Gazeta de Ilhéos, i6 a 30 de outubro de 1904 .

AVÉ-LALLEMANT, Robert. Viagem pelo Norte do Brasil no Ano de I859. Tradução: Eduardo de Lima Castro. Rio de Janeiro: Instituto Nacional do Livro, Ministério da Educação e Cultura, I96I.

BERLIN, Ira. Many Thousands Gone: The First Two Centuries of Slavery in North America. Cambridge: The Belknap Press of Harvard University Press, 1998.

BETHELL, Leslie. The Abolition of the Brazilian Slave Trade. Cambridge: Cambridge University Press, 1970.

CAMPOS, João da Silva. Crônica da Capitânia de São Jorge dos Ilhéos. Edição comemorativa de sua elevação à categoria de Cidade. Rio de Janeiro: Ministério da Educação e Cultura, Conselho Federal de Cultura, 198I.

CANDIDO, Mariana. South Atlantic Exchanges: The role of Brazilian-born agents in Benguela, I650-I850. Luso-Brazilian Review, 50:I (2013), pp. 53-82.

CURTO, José C. Luso-Brazilian alcohol and the legal slave trade at Benguela and its Hinterland (I6I7-I830). In: BONIN, H. e CAHEN, M. (orgs.) Négoce Blanc en Afrique Noire: L'evolution du commerce à longue distance en Afrique noire du I8èmee au zoème siècles. Paris: Publications de la Sociéte française d'histoire d'outre-mer, 200 I. . Struggling Against Enslavement: The Case of José Manuel in Benguela, I8I6-I820. Canadian Journal of African Studies, Revue Canadienne des Études Africaines, Vol. 39, No I 2005, p. 96-I22.

CURTO, José C. e LOVEJOY, Paul E. orgs. Enslaving Connections: Changing Cultures of Africa and Brazil during the Era of the Slave Trade. New York: Humanity Books, 2004.

CRUZ, Ronaldo Lima da. Tráfico clandestino de escravos: a atuação do Juiz de Direito de Ilhéus na apreensão dos africanos desembarcados na Praia de Mamoam. Documentação e Memória /TJPE, jan./dez.20I0, v.2, n.3, p. II9-34.

FERREIRA, Roquinaldo. Biografia, mobilidade e cultura atlântica: a microescala do tráfico de escravos em Benguela, séculos XVIII-XIX. Varia História, vol 2I9, n. 5I, set/dez 20I3, pp. 679-695. 
- Cross-Cultural Exchange in the Atlantic World (Angola and Brazil during the Era of the Slave Trade). New York: Cambridge University Press, 2012.

. Biografia como história social: o clã Ferreira Gomes e os mundos da escravização no Atlântico Sul. Tempo, no 20 (2006), pp. 33-59.

FLORENTINO, Manolo Garcia. Em Costas Negras: uma história do tráfico atlântico de escravos entre a África e o Rio de Janeiro (secs XVIII e XIX). 2. ed. São Paulo: Companhia das Letras, 2002. FRAGA Filho, Walter. Encruzilhadas da Liberdade. Campinas-SP: Editora da UNICAMP, 2006. GILROY, Paul. The Black Atlantic: Modernity and Double Consciousness. Cambridge: Harvard University Press, 1993.

GOMEZ, Michael. Exchanging Our Country Marks: The Transformation of African Identities in the Colonial and Antebellum South. Chapel Hill: University of North Carolina Press, 1998.

HARMS, Robert. River of Wealth, River of Sorrow: The Central Zaire Basin in the Era of the Slave and Ivory Trade, I500-I89I. New Haven, CT: Yale University Press, I98I.

HAWTHORNE, Walter. Being now, as it were, one Family: Shipmate bonding on the slave vessel Emilia, in Rio de Janeiro and throughout the Atlantic World. Luso-Brazilian Review, 45:I (2008), pp. 53-77.

HERSKOVITS, Melville. The Negro in the New World: Statement of a Problem (O negro no Novo Mundo: constatação de um problema). American Anthropologist: New Series, 32:I janeiro I930, pp. I45-I55.

HEYWOOD, Linda (org). Central Africans and Cultural Transformations in the American Diaspora. New York: Cambridge University Press, 2002. - Portuguese into African: The Eighteenth-Century African Background to Atlantic Creole Cultures. In: HEYWOOD, Linda (org). Central Africans and Cultural Transformations in the American Diaspora. New York: Cambridge University Press, 2002, pp. 9I-II6.

LINEBAUGH, Peter e REDIKER, Martin. The Many Headed Hydra: Sailors, Slaves and Commoners and the Hidden History of the Revolutionary Atlantic. Boston: Beacon Press, 2000.

LOVEJOY, Paul C. The Children of Slavery-The Transatlantic Phase. Slavery and Abolition, Vol. 27, No 2, August 2006, p. 197-2I7.

MacGAFFEY, Wyatt. Custom and Government in the Lower Congo. Berkeley, University of California Press, I970. 
Kongo Political Culture: The Conceptual Challenge of the Particular. Bloomington-IN: Indiana University Press, 2000.

MAHONY, Mary Ann. Children's Labor and Social Mobility among Family Cacao Farmers in Brazil, I872-I920. Preparado para apresentação com o Painel sobre Trabalho Infantil na História da América Latina, uma sessão conjunta da American Historical Association, a Conference on Latin American History e a Labor and Working Class History Association, $130^{\circ}$ Encontro anual da American Historical Association, Atlanta, Georgia, 7-Io de janeiro de 2016.

. "Creativity under Constraint: Enslaved Families in Brazil's Cacao Area, I870-I890. Journal of Social History, 4I:3, 2008. p. 633-666.

. Instrumentos necessários: Escravidão e posse de escravos no sul da Bahia no século dezenove. Afro-Ásia, No. 25-26. 200I. p. 95-I39.

. Mulher, família e estatuto social no sul da Bahia: entre a escravidão e a liberdade (c. I850 - c. 1920). In: LIBBY, Douglas Cole, MENESES, José Newton Coelho, FURTADO, Júnia Ferreira, e FRANK, Zephyr L.. (orgs.). Família e Demografia em Minas Gerais: I600-I920. Belo Horizonte: Editora UFMG, 2015, 295-329.

MILLER, Joseph C. Central Africa during the Era of the Slave Trade. In: HEYWOOD, Linda. Africans and Cultural Transformations in the American Diaspora. New York: Cambridge University Press, 2002, pp. 2I-70.

.Way of Death: Merchant Capitalism and the Angolan Slave Trade, I730-I830.

Madison: University of Wisconsin Press, 1988.

PUTNAM, Lara. To Study the Fragment of the Whole: Microhistory and the Atlantic World. Journal of Social History, Vol. 39, Issue 3, 2006, pp. 6I5-630.

REIS, João José. Escravos e coteiros no quilombo do Oitizeiro, Bahia, I8o6. In: REIS e GOMES Liberdade por um Fio: A história dos quilombos no Brasil. 2. ed. São Paulo: Companhia das Letras, 2000. . Rebelião Escrava no Brasil: a história do Levante dos Malês em I835. ed. rev. e amp. São Paulo: Companhia das Letras, 2003.

REIS, João José e GOMES, Flávio. Liberdade por um Fio: A história dos quilombos no Brasil. São Paulo: Companhia das Letras, 2000. 2. ed.

REIS, João José, GOMES, Flávio dos Santos e CARVALHO, Marcus J. M. de. O Alufá Rufino: tráfico, escravidão e liberdade no Atlântico negro (c I822-c I853). São Paulo: Companhia das Letras, 2010. 
SCHWENIGER, Loren. Slavery and Southern Violence: County Court Petitions and the South's Peculiar Institution. The Journal of Southern History, vol. 85, No I/2. 2000. p. 33-35.

SCWARTZ, Stuart B. Slaves Peasants and Rebels. Champaign-Urbana: Illini Books, I996.

SWEET, James H. Recreating Africa: Culture, kinship and religion in the Afro-Portuguese World, I44I-I77O. Chapel Hill: University of North Carolina Press, 2003.

TAVARES, Luis Henrique Dias. Comércio Proibido dos Escravos. São Paulo: Editora Ática, I988.

THORNTON, John. Africa and Africans in the Making of the Atlantic World. 2. ed. Cambridge: Cambridge University Press, 1998.

Religious and Ceremonial Life in the Kongo and Mbundu areas, I500I70o. In: HEYWOOD, Linda, Africans and Cultural Transformations in the American Diaspora. New York: Cambridge University Press, 2002, pp. 7I-90.

VANSINA, Jan. Paths in the Rainforest: Toward a History of Political Tradition in Equatorial Africa. Madison: University of Wisconsin Press, 1990.

VERGER, Pierre. Flux e Reflux de la Traite des Nègres entre le Golfe de Bénim e Bahia de Todos os Santos du XVII au XIX siècle. Paris: Mouton e Co, I968.

WOLF, Eric. Europe and the People without History. Berkeley: University of California Press, I982. 